\title{
KEBENARAN ILMIAH \\ DALAM PEMIKIRAN THOMAS S. KUHN \\ DAN KARL R. POPPER: \\ SUATU KAJIAN HERMENEUTIKA \\ DAN KONTRIBUSINYA BAGI MASA DEPAN ILMU
}

\section{Fuad}

IAIN Ar-Raniry Banda Aceh

Email: fuadramly@yahoo.com

\section{Koento Wibisono S.}

Fakultas Filsafat, Universitas Gadjah Mada

\section{P. Hardono Hadi}

Pengajar di Program Pascasarjana Ilmu Filsafat Universitas Gadjah Mada

\section{Abstrak}

Pemikiran Kuhn tentang kebenaran ilmiah tercermin dari normal science (periode kemajuan ilmiah) dan Popper dari verisimilitude (sesuatu yang mirip kebenaran sejati). Hermeneutika Kuhn bercorak fenomenologis karena hanya memahami kebenaran (ilmiah) berdasarkan fenomena kemajuan ilmiah, sedangkan Hermeneutika Popper bercorak ontologis karena meyakini adanya kebenaran absolut (metailmiah). Persamaan esensial Hermeneutika Kuhn dan Popper karena mengakui kebenaran ilmiah yang bersifat "relatif-ideal" (tetap selamanya relatif) atau tidak akan pernah absolut. Perbedaan fundamental Hermeneutika Kuhn dan Popper karena Kuhn bertitik-tolak dari dimensi deskriptif, sedangkan Popper bertitik-tolak dari dimensi normatif. Hermeneutika Kuhn dan Popper dapat dikontribusikan sebagai landasan filosofis pengembangan ilmu, yaitu: wilayah penyelidikan ilmiah sebagai landasan ontologis, dialektika kemajuan ilmiah sebagai landasan epistemologis, dan menuju kebenaran absolut-transendental sebagai landasan aksiologis. Hermeneutika Kuhn dan Popper juga dapat dikontribusikan bagi upaya reintegrasi ilmu dan filsafat, terkait korelasi dan interkoneksi dimensi empiris dan metafisik, yang sekaligus dapat dijadikan dasar untuk memahami demarkasi ilmu (sistem pengetahuan empiris) dan filsafat (sistem pengetahuan metafisik). Hermeneutika Kuhn dan Popper juga dapat dikontribusikan untuk mewujudkan integrasi Ilmu-ilmu Kealaman dan Ilmu-ilmu Kemanusiaan (dan Sosial) di Indonesia, da- 
lam rangka pengembangan IPTEK yang relevan dengan nilai-nilai etika Pancasila.

Kata kunci: kebenaran relatif-ideal; dialektika kemajuan ilmiah; kebenaran absoluttransendental.

\section{Abstract}

The scientific truth can be identified on the Kuhn's normal science as a period of scientific progress, and on the Popper's verisimilitude (the truthlikeness). The Kuhn's thought is a phenomenological hermeneutics due to his understanding to the scientific truth according to the phenomenon of scientific progress, and otherwise the Popper's is an ontological hermeneutics which acknowledges the absolute truth beyond the scientific explanation. The essential similarity of Kuhn and Popper's hermeneutics is justifying the scientific truth as a relativeideal one (never be the absolute one), and the fundamental difference of both of them caused by Kuhn's hermeneutics based on a descriptive approach and Popper's by the normative one. The Kuhn and Popper's hermeneutics can be contributed to be a philosophical foundation of science, namely: the scientific investigation area (ontological foundation), the dialectic of scientific progress (epistemological foundation), and toward the absolute-transcendental truth (axiological foundation). The hermeneutics can also be contributed to reintegrate science and philosophy, as a correlation and interconnection entity of empirical and metaphysical dimension, and can spontanously be an understanding frame of the demarcation of science (a system of empirical knowledge) and philosophy (a system of metaphysical one). The hermeneutics can be contributed to implement the integration of Natural Sciences and Humanities (and Social Sciences) in Indonesia, as an IPTEK development strategy which is relevant to the ethical values of the Pancasila's.

Keywords: the relative-ideal truth; the dialectic of scientific progress; the absolutetranscendental truth.

\section{PENDAHULUAN}

Penelitian ini dilatarbelakangi problematika kemajuan ilmiah yang berlangsung sampai pada masa sekarang yang memunculkan berbagai polemik, kritik dan kontroversi. Kemampuan dan keunggulan ilmu mulai dipertanyakan karena esensi realitas sesungguhnya mengatasi segala bentuk pengetahuan ilmiah yang dihasilkan manusia. Ilmu hanya dipandang mampu menghasilkan pengetahuan yang ter- 
batas dengan menguji secara reflektif kondisi-kondisi fondasional tentang klaim kebenaran yang dihasilkannya (Ambrosio, 1987: 17). Ilmu pada abad ke-20 telah membuktikan ketidakmampuannya memberikan penjelasan tentang realitas secara utuh dan definitif, karena manusia pada dasarnya tidak pernah berurusan dengan kebenaran korespondensi di dalam ilmu, kecuali hanya pengetahuan terbatas berupa perkiraan-perkiraan (Capra, 2010:211).

Fenomena tersebut memunculkan berbagai persoalan tentang esensi dan eksistensi ilmu yang berimplikasi pada kebenaran ilmiah, sebagaimana yang berkembang di dalam kajian-kajian filsafat ilmu masa kini. Persoalan-persoalan ini secara umum masih merupakan teka-teki yang belum terjawab secara memuaskan, dan telah memicu perdebatan Thomas S. Kuhn (1922-1996) dan Karl R. Popper (19021994). Giddens (1976: 136) mengatakan bahwa perdebatan Kuhn dan Popper terkait dengan persoalan "normal science" yang dinyatakan Kuhn sebagai periode keberhasilan paradigma-paradigma ilmiah.

Perdebatan tersebut merupakan salah satu peristiwa terpenting dalam sejarah filsafat ilmu. Hull (1996: 203) menilai Kuhn dan Popper sebagai filsuf ilmu yang paling berpengaruh pada jaman sekarang. Blackburn (1994: 209) dan Sardar (2002: 24) juga mencatat Kuhn sebagai salah satu filsuf terkemuka yang paling berpengaruh dalam bidang sejarah dan filsafat ilmu pada abad ke-20, dan Klemke (1981: 260) menjuluki Popper sebagai salah satu filsuf terbesar abad ke-20.

Perdebatan tersebut menciptakan bipolaritas persoalan ilmiah yang lebih luas: historisitas dan normativitas ilmu; idealitas in abstracto dan realitas in concretto ilmu; context of justification dan context of discovery ilmu; juga kritik terhadap kecenderungan positivistik yang sudah mengakar dalam tradisi ilmu-ilmu sampai kepada tendensi hermeneutik yang mulai bersentuhan dengan perkembangan ilmu-ilmu. Persoalan-persoalan tersebut terkait erat dengan dunia ilmu dan filsafat, yang seluruhnya berimplikasi pada pandangan dunia (world view) kontemporer, wacana-wacana postmodernisme, dan terutama sekali diskursus hermeneutika (Hermeneutics) yang sedang bergulir akhir-akhir ini. 
Palmer (1969: 42-43) mengatakan bahwa hermeneutika mencakup seluruh pertanyaan filosofis yang menghubungkan bahasa dengan pemahaman, eksistensi, realitas, dan Yang-Ada (Being). Hermeneutika merupakan pusat persoalan-persoalan filsafat dewasa ini yang tidak luput dari aspek ontologis dan epistemologis. Hermeneutika juga mempersoalkan pemahaman tentang kebenaran sebagai masalahmasalah ontologis dan epistemologis, yaitu kebenaran tentang kenyataan dan kebenaran tentang pengetahuan. Bleicher (1980: 109) bahkan menegaskan bahwa filsafat ilmu dewasa ini juga tidak dapat terlepas dari hermeneutika karena persoalan-persoalan hermeneutik mendasari seluruh bentuk pengetahuan manusia.

Penelitian ini difokuskan pada penelaahan "pemikiran Kuhn dan Popper tentang kebenaran ilmiah" (objek material) sebagai kajian "Hermeneutika" (objek formal), berikut kontribusinya bagi masa depan ilmu. Tujuan utamanya adalah menyajikan hermeneutika Kuhn dan Popper sebagai alternatif pemahaman baru, serta menawarkan kontribusinya bagi pengembangan ilmu untuk masa depan.

Penelitian ini berlandaskan dua teori utama: "historicality of understanding" dan "dialectic of understanding", terkait dengan ontologi dan fenomenologi pemahaman, yang merupakan ajaran filsafat hermeneutika Hans-Georg Gadamer. Kedua teori tersebut dipergunakan untuk menelaah pemikiran Kuhn tentang "revolusi paradigma ilmiah" dan pemikiran Popper tentang "falsifikasi teori ilmiah" terkait dengan dimensi ontologis-normatif dan dimensi historis-deskriptifnya.

\section{HERMENEUTIKA THOMAS S. KUHN DAN KARL R. POPPER}

Kata "hermeneutik" (hermeneutika) berasal dari bahasa Yunani, dari kata "hermeneuein" yang berarti "menafsirkan", dan dari kata benda "hermeneia" yang secara etimologis dapat diartikan "penafsiran" atau "interpretasi" (Sumaryono, 1993: 23). Gadamer (1976: xi) mengatakan bahwa hermeneutika merupakan ontologi dan fenomenologi pemahaman, yang mengkaji "hakikat" pemahaman dan "proses penyingkapannya" melalui berbagai peristiwa (fenomena) pemahaman. 
Hermeneutika bertujuan "menyingkap" pengetahuan universal (esensi pengetahuan) melalui ontologi pemahaman, bukan prosedur atau metode pemahaman untuk "menangkap" pengetahuan universal secara definitif (Gadamer, 1975: 263 bdkn Gadamer, 1988: 27). Sinyalemen tersebut relevan dengan pandangan epistemologi masa kini. Epistemologi menuntut keterbukaan bermacam arti pengetahuan dengan berbagai cara mengetahui, termasuk upaya "menafsirkan" nilai kognitif pengalaman manusia, yang tidak boleh tertutupi oleh sistem filosofis tertentu (Hadi, 1994: 24-27).

\section{Corak Hermeneutika Thomas S. Kuhn}

Kuhn mengembangkan hermeneutika yang bercorak fenomenologis dalam memahami kebenaran ilmiah yang dihasilkan oleh periode-periode normal science, sebagai fenomena kemajuan ilmiah, yang berlangsung di dalam setiap paradigma. Pemahaman fenomenologis dalam Hermeneutika Gadamer (1975: 266) adalah pemahaman partikular yang berkembang dalam berbagai peristiwa (fenomena) pemahaman. Lye (1996) mengidentifikasi bentuk pemahaman ini sebagai hermeneutika fenomenologis (phenomenological hermeneutics) yang bersandarkan prinsip: "We live in the world: in history, in concretion: we do not live any where else, and all meaning is only meaning in relation to particular, concrete, historical existence."

Pemahaman fenomenologis melahirkan konsep kebenaran fenomenologis. Kebenaran fenomenologis dalam hermeneutika Gadamer (1975: 266) merupakan kebenaran-kebenaran partikular yang dihasilkan dari pemahaman-pemahaman partikular (berbagai peristiwa pemahaman).

Kebenaran fenomenologis dalam hermeneutika Kuhn tercermin dari partikularitas kebenaran ilmiah yang dihasilkan oleh setiap periode normal science yang bersifat tentatif dan relatif. Sifat tentatif dan relatif kebenaran ilmiah muncul manakala normal science mengalami anomali dan krisis yang berakibat revolusi dan lahirnya paradigma baru dengan normal science yang baru, dan demikian seterusnya. 
Kemajuan ilmiah yang ditandai dengan kemenangan setiap paradigma baru menyiratkan "kekuasaan" (authority) tersebut adalah "benar" (right) karena merupakan hasil kewenangan profesional komunitas ilmiah. Kemajuan melalui perubahan paradigma tersebut bukanlah semakin mendekati kebenaran (Kuhn, 1970a: 167, 170) esensial (ontologis), kecuali hanya kebenaran ilmiah menurut paradigma masing-masing.

Kebenaran ilmiah hanya bersifat partikular, tanpa kontinuitas atau akumulasi yang mengarah kepada kebenaran ontologis yang bersifat universal. Kuhn memahami kebenaran ilmiah dalam konteks incommensurability of paradigms (ketidakterukuran antarparadigma), dan setiap paradigma baru senantiasa meruntuhkan setiap paradigma lama, sehingga kebenaran ilmiah tersekat-sekat oleh paradigma masing-masing tanpa korelasi dan kesinambungan satu sama lain.

Penjelasan tersebut menyiratkan Kuhn sebagai reduksionis, yang mereduksi kebenaran ontologis ke dalam wilayah kebenaran fenomenologis. Kebenaran ontologis sama sekali luput dari konteks pemahaman tentang kemajuan ilmiah, karena satu-satunya bentuk kebenaran adalah kebenaran fenomenologis (kebenaran ilmiah). Tidak terdapat pemahaman tentang entitas kebenaran metailmiah, yang berdiri sendiri (independent) atau terlepas dari realitas historis kemajuan ilmiah.

\section{Corak Hermeneutika Karl R. Popper}

Popper mengembangkan hermeneutika yang bercorak ontologis, dalam rangka memahami kebenaran "absolut" sebagai tujuan ultim dari kemajuan ilmiah yang berlangsung melalui proses falsifikasi teori ilmiah secara terus-menerus dan berkesinambungan. Pemahaman ontologis dalam Hermeneutika Gadamer (1975: 266) digambarkan sebagai pemahaman universal, yang merupakan modus interpretendi untuk mengungkap kebenaran universal, yang secara kategoris terbedakan dari pemahaman partikular yang hanya menyajikan kebenaran-kebenaran faktual atau fenomenal. 
Pemahaman ontologis tersebut memunculkan konsekuensi kebenaran ontologis. Kebenaran ontologis dalam Hermeneutika Gadamer (1975: 158, 264) adalah kebenaran universal yang "dapat" dipahami melalui pemahaman universal (dalam dialog interpretatif universal), "seandainya" pemahaman universal itu terwujud. Noeng Muhadjir (2001: 13, 137) berpendapat bahwa kebenaran objektif universal tidak dapat dibuktikan dan untestable, kecuali sebab-akibat dari kejadiankejadian yang terkait di dalamnya. Kebenaran ontologis juga lazimnya bersifat metafisik, berbeda dengan kebenaran-kebenaran fenomenologis yang bermuatan empiris, dan mengatasi gejala-gejala (fenomena) pengetahuan manusia (Verhaak dan Imam, 1997: 129). Kebenaran ontologis tersebut dalam pengertian tertentu juga bersifat "absolut".

Kebenaran ilmiah dalam hermeneutika Popper dapat dipahami dari konteks kebenaran absolut (kebenaran ontologis) terkait dengan pemahaman ontologis tentang falsifikasi teori ilmiah. Falsifikasi teori ilmiah merupakan proses pemahaman fenomenologis yang berlangsung secara terus-menerus dalam menemukan kebenaran-kebenaran fenomenologis (kebenaran ilmiah) - yang diistilahkan dengan verisimilitude (sesuatu yang mirip kebenaran absolut). Kebenaran-kebenaran fenomenologis, yang bersifat tentatif, relatif dan partikular, adakalanya dihasilkan oleh teori-teori baru atau bahkan oleh teori-teori lama yang telah dikorroborasi. Kebenaran-kebenaran fenomenologis, yang dihasilkan oleh proses falsifikasi ini secara terus-menerus, senantiasa mengarah atau semakin mendekati kebenaran absolut.

Popper secara eksplisit mengakui dirinya bukan relativis, karena meyakini kebenaran "absolut" atau "objektif", dan juga menyatakan dirinya bukan "absolutis" atau orang yang mengaku telah menangkap kebenaran absolut tersebut. Popper mengatakan: "Only in our subjective experiences of conviction, in our subjective faith, can we be 'absolutely certain" (Popper, 1972: 56, 280). Kebenaran absolut tidak mungkin dapat dicapai oleh manusia, dan karenanya Popper menyatakan kebenaran ilmiah hanyalah sebagai verisimilitude (sebatas mirip/mendekati kebenaran absolut). 
Popper hanya berupaya menjelaskan bagaimana memahami kebenaran yang semestinya berlaku dalam dunia ilmiah, berdasarkan prinsip falsifiabilitas (kemungkinan falsifikasi teori-teori ilmiah). Kebenaran ilmiah dapat ditransendesikan ke arah kebenaran absolut melalui falsifikasi teori-teori ilmiah dalam durasi yang tidak terbatas.

Penjelasan tersebut mengidentifikasikan Popper sebagai transendentalis, yang mentransendensikan kebenaran ilmiah (fenomenologis) ke arah kebenaran absolut yang bersifat ontologis. Terdapat pemahaman tentang entitas kebenaran metailmiah (kebenaran absolut), yang bersifat independen atau terlepas dari realitas historis kemajuan ilmiah.

\section{Persamaan Hermeneutika Thomas S. Kuhn dan Karl R. Popper}

Persamaan Hermeneutika Kuhn dan Popper pertama-tama dapat diidentifikasi dari pemahaman tentang keterbatasan ilmu sebagaimana yang telah dijelaskan di atas. Kuhn dan Popper pada prinsipnya ingin menyatakan secara clear and distinct bahwa ilmu tidak akan mampu menyajikan kebenaran absolut tentang realitas, sekalipun proses revolusi paradigma ilmiah (Kuhn) dan falsifikasi teori ilmiah (Popper) berlangsung secara terus-menerus dan berkesinambungan dalam seluruh rangkaian perjalanan kemajuan ilmiah.

Pemahaman tersebut juga menyiratkan suatu bentuk persamaan esensial Hermeneutika Kuhn dan Popper, bahwa ilmu hanya mampu menyajikan kebenaran-kebenaran "relatif" tentang berbagai fenomena realitas, sebagai satu-satunya bentuk kebenaran ilmiah. Sinyalemen ini juga tercermin dari pernyataan Kuhn (1970a: 146) bahwa tidak ada teori ilmiah yang pernah memecahkan seluruh teka-teki pada suatu waktu tertentu, dan pemecahan-pemecahan yang telah dicapai jarang yang lengkap dan sempurna.

Kebenaran ilmiah yang bersifat relatif bukanlah kontraproduktif bagi ilmu yang dapat mereduksi otoritas penyelidikan ilmiah. Kebenaran relatif ini justru sangat konstruktif dan produktif bagi keberlangsungan kemajuan ilmiah untuk masa-masa yang akan datang, karena memberi peluang bagi spirit kritisisme ilmiah itu sendiri dalam me- 
ngatasi segala bentuk dogmatisme dan determinisme yang dapat mereduksi nilai-nilai kreativitas ilmiah.

Para ilmuwan ditantang untuk menciptakan kemajuan-kemajuan baru dalam rangka menemukan kebenaran baru, guna melengkapi atau menyempurnakan kebenaran lama, karena kebenaran relatif yang telah dihasilkan. Karena kebenaran baru juga bersifat relatif, para ilmuwan dapat terus-menerus (secara dialektis) mengembangkan kreativitasnya untuk melahirkan kebenaran-kebenaran berikutnya, dan demikian seterusnya. Hal ini dapat dimungkinkan karena kebenaran ilmiah yang bersifat relatif juga mengandung karakteristik dialektis, sebagaimana tercermin dari pernyataan Kuhn (1970a: 100) bahwa ilmu senantiasa dapat dikembangkan lebih lanjut melalui penyelidikan ilmiah itu sendiri.

Karakteristik dialektis kebenaran relatif tersebut juga dapat dipahami dari potensi setiap normal science (yang menyajikan kebenaran relatif) yang membangkitkan anomali, krisis, dan melahirkan paradigma-paradigma baru (dalam proses revolusi) yang menghasilkan periode-periode normal science yang baru (yang menyajikan kebenarankebenaran relatif selanjutnya). Kuhn (1970a: 52) menegaskan bahwa sejarah telah mencatat kehebatan normal science dalam mengembangkan kegiatan dan kekuatan ilmiah yang tiada bandingannya, melahirkan kejutan-kejutan baru yang tidak terduga, ketika para ilmuwan menyingkap fakta-fakta baru dan teori-teori baru yang fundamental. Normal science justru sangat efektif mendorong terjadinya perubahan paradigma, dalam rangka melahirkan paradigma-paradigma baru.

Karakteristik dialektis tersebut juga dapat dipahami dari potensi teori lama yang dikorroborasi (yang menyajikan kebenaran relatif) yang dapat difalsifikasi lagi secara terus-menerus untuk melahirkan teori baru atau meningkatkan korroborasi teori lama (yang menyajikan kebenaran-kebenaran relatif berikutnya). Kuhn (1970a: 146) menyatakan bahwa peran yang ditunjukkan oleh falsifikasi Popper sangat mirip dengan pengalaman-pengalaman yang diperlihatkan oleh anomali, yang membangkitkan krisis dan merintis jalan kepada suatu teori baru. 
Penjelasan tersebut menegaskan keniscayaan kebenaran ilmiah relatif yang bersifat "ideal" (tetap dan tidak berubah), atau selamanya relatif dan tidak akan pernah absolut. Popper (1972: 278-280) mengatakan bahwa ilmu bukanlah episteme (pengetahuan) yang dapat melahirkan suatu klaim perolehan kebenaran dan kepastian absolut sebagaimana cita-cita episteme ilmiah lama, karena klaim tersebut hanyalah sebuah "berhala". Ilmu merupakan petualangan abadi untuk menggapai pengetahuan dan kebenaran yang merupakan motif utama penemuan ilmiah.

\section{Perbedaan Hermeneutika Thomas S. Kuhn dan Karl R. Popper}

Perbedaan hermeneutika Kuhn dan Popper pertama-tama dapat ditelusuri dari coraknya masing-masing, terkait dengan pemahaman tentang "kebenaran". Kebenaran dalam pandangan Kuhn hanya bersifat fenomenologis, sebagaimana halnya kebenaran ilmiah, karena hermeneutika Kuhn bercorak fenomenologis. Kebenaran dalam pandangan Popper bersifat ontologis (kebenaran absolut), karena hermeneutika Popper bercorak ontologis, sehingga kebenaran ilmiah hanya bersifat verisimilitude (mirip kebenaran ontologis). Perbedaan pemahaman ini bermuara pada suatu perbedaan fundamental, yaitu titik-tolak pemahaman.

Hermeneutika Kuhn bertitik-tolak dari dimensi "deskriptif", dan karenanya bercorak fenomenologis. Dimensi deskriptif ini, yang mencirikan modus interpretendi Kuhn, terlihat dari pemahamannya yang hanya menggambarkan kebenaran ilmiah berdasarkan fenomena atau fakta historis kemajuan ilmiah, tanpa muatan normatif atau aspek ontologisnya. Gambaran historisitas kemajuan ilmiah mencerminkan normativitasnya, karena Kuhn mereduksi aspek normatif ke dalam wilayah deskriptif.

Kemajuan ilmiah yang berlangsung di dalam paradigma menurut pemahaman Kuhn bukan sekedar bersifat historis-deskriptif, tetapi sekaligus juga historis-normatif. Kuhn mempergunakan ide "paradigma" hanya secara teoritis dan deskriptif (Jacobs and Mooney, 1997: 479) tanpa muatan normatif, dan memandang konsep kontinuitas ilmu 
yang bersifat sosio-psikologis sebagai sesuatu yang normatif (Lakatos, 1970:177), bukan sekedar deskriptif.

Kuhn meyakini di dalam dunia ilmiah sesuatu "yang-deskriptif" identik dengan "yang-normatif", sebagaimana diperlihatkan oleh peran teori ilmiah. "Teori" mempunyai konsekuensi bagi keberhasilan para ilmuwan, karena teori menyajikan dasar yang valid bagi tindakan "sepantasnya" yang memang "seharusnya" dilakukan para ilmuwan. Keberhasilan para ilmuwan dikarenakan memilih dan mengembangkan metode-metode yang telah diharuskan oleh teori tersebut (Kuhn, 1970a: 207-208).

Hermeneutika Popper bertitik-tolak dari dimensi "normatif", dan karenanya bercorak ontologis. Dimensi normatif ini, yang mencirikan modus interpretendi Popper, terlihat dari pemahamannya yang mengatasi kebenaran ilmiah yang bersifat fenomenologis (verisimilitude), dalam rangka memahami (menyingkap) kebenaran ontologis (absolut) yang diyakini sebagai kebenaran sejati. Normativitas kebenaran absolut mengatasi segala bentuk gambaran historisitas kebenaran ilmiah yang dihasilkan oleh kemajuan-kemajuan ilmiah. Popper lebih mengedepankan dimensi normatif kebenaran (kebenaran yang seharusnya dipahami dan diyakini) daripada gambaran deskriptifnya, berbeda dengan Kuhn yang hanya mengandalkan dimensi deskriptifnya (kebenaran yang tercipta dari peristiwa-peristiwa yang terjadi, sebagaimana halnya kebenaran ilmiah itu sendiri).

Kemajuan-kemajuan teoritis ilmiah menurut pandangan Popper "seharusnya" memiliki karakter revolusioner, sebaliknya Kuhn justru menilai kemajuan-kemajuan tersebut "sudah" memiliki karakter revolusioner (Watkins, 1970: 37). Popper mengakui kenyataan historis-faktual normal science, tetapi tidak disukai dan "seharusnya" tidak terjadi karena dipandang berbahaya bagi ilmu, meskipun Kuhn berpendapat bahwa normal science merupakan sesuatu yang normal. Popper juga menegaskan bahwa normal scientist yang digambarkan Kuhn keliru karena telah menjadi ilmuwan terapan (applied scientist), yang bertentangan dengan yang "seharusnya" yaitu ilmuwan murni (pure scientist) (Popper, 1970: 52-53). 


\section{KONTRIBUSI BAGI MASA DEPAN ILMU}

Hermeneutika Kuhn dan Popper dapat dikontribusikan sebagai landasan filosofis (ontologis, epistemologis, aksiologis) pengembangan ilmu untuk masa depan. Ketiga landasan filosofis ini dapat dijelaskan sebagai berikut.

Wilayah penyelidikan ilmiah merupakan landasan ontologis ilmu, terkait dengan pemahaman hakikat ilmu dan objek kajiannya. Wilayah penyelidikan ilmiah, sebagai objek kajian ilmu-ilmu empiris, merupakan realitas fenomenologis (dunia nyata, alam fisik, atau fenomena), yang dapat dibedakan secara ketegoris (bukan dikotomis) dari realitas ontologis (metailmiah/metafisik). Penyelidikan ilmiah harus dibatasi pada wilayah fenomenologis karena karakteristik metodologisnya yang empiris. Metode yang semata-mata mendasarkan semua model dan teori pada data empiris adalah esensi pendekatan ilmiah (Capra, 2010: 210).

Wilayah fenomenologis menurut hermeneutika Kuhn merupakan objek kajian ilmiah yang dilandasi oleh paradigma-paradigma. Kebenaran pemahaman wilayah fenomenologis hanya berlangsung pada periode-periode normal science dari setiap paradigma. Konsep kebenaran tersebut dapat memperkokoh otoritas ilmu-ilmu empiris.

Sedangkan wilayah fenomenologis menurut hermeneutika Popper adalah objek kajian ilmiah yang terlibat di dalam proses falsifikasi teori. Kebenaran pemahaman wilayah fenomenologis bersifat verisimilitude, yang tercipta karena korroborasi teori lama dan terutama kelahiran teori baru. Kebenaran yang bersifat absolut atau objektif hanyalah kebenaran pemahaman wilayah ontologis yang tidak mungkin dapat dicapai secara definitif, total, dan final oleh penyelidikan ilmuilmu empiris. Kedua wilayah tersebut tetap bersifat korelatif dan interkonektif, bahwa kebenaran-kebenaran wilayah fenomenologis (empiris) senantiasa semakin mendekati kebenaran absolut (metafisik/ontologis).

Dialektika kemajuan ilmiah merupakan landasan epistemologis ilmu, menyangkut pemahaman tentang perkembangan penyelidikan ilmiah. Perkembangan penyelidikan ilmiah masa kini dapat dikatakan 
sebagai perkembangan "kemajuan ilmiah". Setiap upaya pemahaman tentang esensi dan eksistensi ilmu difokuskan pada problematika kemajuan ilmiah dalam rangka memahami kebenaran ilmiah. Niiniluoto (2011) mengatakan bahwa kemajuan ilmiah mengandung hubungan faktual dengan kemajuan teknologis dan kemajuan sosial. Teori tentang kemajuan ilmiah harus menggambarkan spesifikasi nilai-nilai dan tujuan-tujuan yang mengindikasikan kriteria ilmu yang mumpuni (good science) - atau normal science menurut istilah Kuhn.

Teori-teori tentang kemajuan ilmiah bahkan menggambarkan "kebenaran" sebagai tujuan penting dari penyelidikan ilmiah, sebagaimana yang dikembangkan oleh kaum realis. Kaum realis ilmiah bersandar pada pemahaman bahwa fakta keberhasilan empiris adalah indikasi terbaik bagi kemajuan yang sesungguhnya, yang mengandung kebenaran atau kemiripan-dengan-kebenaran (truthlikeness) (Niiniluoto, 2011) sebagaimana pendapat Popper.

Teori-teori ilmiah tersebut, betapa pun handal dan berhasil dalam menjelaskan fakta-fakta, tetap tidak dapat luput dari kemungkinan keberhasilan falsifikasi sebagaimana yang ditegaskan Popper. Capra (2010: 210) juga berpendapat bahwa sebuah teori yang sudah diterima secara bertahap pun akan runtuh jika muncul bukti yang bertentangan.

Penjelasan tersebut mengindikasikan keniscayaan dialektika kemajuan ilmiah melalui proses falsifikasi teori sebagaimana yang dinyatakan Popper (1972: 275) dan gabungan verifikasi-falsifikasi teori dalam proses revolusi paradigma yang dijelaskan oleh Kuhn (1970a: 147). Berbeda dengan keberhasilan verifikasi, keberhasilan falsifikasi sebuah teori justru menyebabkan terjadinya anomali - sebagaimana akibat kegagalan verifikasi-yang dapat mengeleminasi unsur-unsur hipotesis sebuah teori dan bahkan meruntuhkan teori tersebut.

Keruntuhan teori lama dan kelahiran teori baru akibat keberhasilan falsifikasi pada prinsipnya tidak akan mereduksi otoritas kemajuan ilmiah. Kegagalan teori lama dalam mengantisipasi anomali yang menyebabkan lahirnya teori baru "justru" mengindikasikan keberhasilan teori ilmiah secara keseluruhan, sebagaimana dinyatakan Niini- 
luoto (2011): "Here the concept of anomaly refers to a problem that a theory fails to solve, but is solved by some of its rivals."

Kemajuan ilmiah yang berlangsung secara dialektis dari teoriteori lama ke teori-teori baru senantiasa memperkokoh bangunan teori ilmiah itu sendiri. Dialektika kemajuan ilmiah, yang berlangsung secara terus-menerus dan berkesinambungan, merupakan proses transendensi pemahaman kebenaran ilmiah menuju pemahaman kebenaran absolut-transendental.

Menuju kebenaran absolut-transendental merupakan landasan aksiologis ilmu, yang mengandung pemahaman tentang nilai tertinggi sebagai tujuan ultim dari penyelidikan ilmiah, yang berlangsung melalui dialektika kemajuan ilmiah. Dialektika kemajuan ilmiah sekaligus menggambarkan hubungan yang tidak terpisahkan antara perkembangan teori ilmiah dan perkembangan kebenaran ilmiah.

Kaum realis umumnya mengakui bahwa jenis pembuktian yang biasanya dipandang penting bagi penerimaan hukum atau teori ilmiah adalah pembuktian, atau setidaknya perkiraan, tentang kebenaran hukum atau teori ilmiah (Laudan, 1981: 29-30). Kendati ilmu tidak dapat menyediakan sebuah kepastian secara seratus persen, namun diyakini sebagai cara yang "objektif" bagi pencarian pengetahuan untuk menemukan kebenaran (Malhotra, 1994).

Kemajuan ilmiah ditunjukkan oleh indikator keberhasilan dan keunggulan teori-teori ilmiah menjelaskan fenomena-fenomena alamiah yang dapat dipertanggungjawabkan sebagai suatu kebenaran ilmiah. Kebanyakan filsuf menyimpulkan bahwa kebenaran ilmiah merupakan tujuan penting dari penyelidikan ilmiah (Niiniluoto, 2011). Kebenaran ilmiah, sebagai produk teori-teori ilmiah, dihasilkan oleh periode normal science (yang digambarkan Kuhn) dan peristiwa verisimilitude (yang dijelaskan Popper) sebagai periode dan peristiwa kemajuan ilmiah.

Dialektika kemajuan ilmiah berlangsung melalui perkembangan kualitas dan kapasitas kebenaran ilmiah yang terkandung di dalam teori-teori ilmiah secara terus-menerus dan berkesinambungan. Perkembangan ini berlangsung dalam rangka transendensi kebenaran- 
kebenaran fenomenologis (singular/partikular), dan bukan suatu bentuk pencapaian kebenaran universal (ontologis). Kebenaran universal tidak mungkin dapat "ditangkap" secara definitif oleh pemahaman fenomenologis manusia. Popper (1972: 28) menegaskan bahwa kebenaran singular yang dapat dibuktikan oleh pengalaman melalui observasi dan eksperimentasi tidak mungkin melahirkan suatu pemahaman tentang kebenaran universal.

Kebenaran universal yang dimaksudkan oleh Popper juga dapat dipahami sebagai kebenaran absolut-transendental yang bersifat metailmiah (metafisik/ ontologis). Charlton (2009: 373) menegaskan bahwa kebenaran transendental berada di luar ranah ilmu; melampaui metode-metode, proses-proses, atau konsensus ilmiah. Istilah "transendental" bermakna sebagai nilai yang tertinggi, sebagai sasaran yang dituju, bukan pengetahuan yang dapat dicapai atau dapat diukur secara sempurna.

Kebenaran ilmiah dapat dipahami sebagai bagian yang tidak terpisahkan dari pemahaman kebenaran absolut-transendental. Kebenaran ilmiah merupakan salah satu "jalan" untuk menuju kebenaran absolut-transendental sebagai bentuk kebenaran yang tertinggi, karena kebenaran ilmiah akan senantiasa berkembang seiring dengan perkembangan teori-teori ilmiah dalam konteks kemajuan ilmiah yang berlangsung secara terus-menerus dan berkesinambungan secara dialektik. Wallis (2008: 78) menegaskan bahwa terdapat suatu dunia realitas atau kebenaran absolut yang mengatasi pemahaman manusia. Teori-teori yang sudah maju (improved theories) hanya mampu membawa pemahaman manusia untuk "lebih mendekati" kebenaran tertinggi tersebut.

\section{Reintegrasi Ilmu dan Filsafat}

Filsafat pada masa Yunani Kuno tidak dibedakan dengan ilmu. Istilah "philosophia" sinonim dengan istilah "episteme", keduanya menunjukkan suatu bentuk pengetahuan yang sistematis dan rasional (Liang Gie, 2012: 1). Model pemahaman ini kemudian mengalami reduksi, akibat lepasnya ilmu-ilmu cabang dari "batang' filsafatnya di- 
awali oleh fisika dan ilmu-ilmu kealaman, serta diikuti oleh ilmu-ilmu sosial yang mengikuti model ilmu-ilmu kealaman tersebut (Wibisono, 1997:3).

Pemisahan tersebut terjadi sejak Abad ke-17, manakala filsafat kealaman telah menjadi ilmu kealaman yang kemudian dikenal dengan fisika. Pemisahan semacam ini kemudian diikuti oleh biologi pada abad ke-19 dan psikologi pada sekitar pertengahan abad ke-19. Cabang-cabang ilmu yang lain, seperti sosiologi, antropologi, ilmu ekonomi, dan ilmu politik kemudian juga secara tegas terpisah dari filsafat (Liang Gie, 2012: 13).

Pemisahan ilmu dan filsafat, yang berkembang pada jaman modern, diakibatkan perbedaan ciri-cirinya yang semakin kentara. Kebanyakan filsafat masih bercorak spekulatif, sedangkan ilmu-ilmu modern telah menerapkan metode-metode empiris, eksperimental, dan induktif. Pada masa modern semua cabang ilmu dinyatakan sebagai ilmu-ilmu empiris, sebagai ciri umum ilmu yang membedakannya dari filsafat (Liang Gie, 2012: 15).

Persoalan tersebut memunculkan dikotomi ilmu (science) dan filsafat (philosophy) - kecuali dalam kajian filsafat ilmu (Philosophy of Science) yang memperlihatkan korelasi dan interkoneksi ilmu dan filsafat. Dikotomi ini tercermin dari disintegrasi unsur-unsur ilmiah (empiris) dan unsur-unsur filosofis (terutama metafisik) di dalam dunia penyelidikan ilmiah.

Konsekuensi dari dikotomi ilmu dan filsafat, di antaranya, dapat melahirkan anomali yang sangat serius karena penyelidikan ilmiah hanya berkutat dengan gejala-gejala empiris dan mengabaikan unsurunsur non-empiris atau metafisik (filosofis) yang terkait di dalamnya. Pengabaian ini ternyata dapat menimbulkan krisis dan mengancam otoritas paradigma yang melandasi kegiatan-kegiatan para ilmuwan.

Kuhn (1970a: 81) menegaskan bahwa kesadaran para ilmuwan dalam menanggapi terjadinya anomali tidak selamanya berhasil seperti yang diharapkan. Anomali juga bukan hanya terjadi karena faktor eksternal ilmu (munculnya gejala metaempiris), tetapi juga faktor internalnya akibat kelemahan dan keterbatasan otoritas ilmu. T. Jacob 
(1993: 7) menyatakan bahwa ilmu tidak dapat memecahkan seluruh persoalan kehidupan dewasa ini karena keterbatasan otak dan akal manusia, serta peralatan pengamatan yang belum memadai, sehingga dunia objektif menjadi realitas yang disederhanakan.

Persoalan fundamental lainnya, yang juga terkait dengan dikotomi ilmu dan filsafat, bahkan mencuat dalam bentuk penolakan terhadap "metafisika" (salah satu unsur terpenting filsafat) yang diproklamasikan oleh positivisme logis, salah satu mazhab filsafat ilmu kontemporer. Dikotomi ilmu dan filsafat mencapai titik kulminasi (puncak), melalui eliminasi (penyisihan) metafisika dari dunia ilmiah. Positivisme logis mengajarkan bahwa proposisi-proposisi ilmiah dapat dinyatakan benar (meaningful) apabila mengandung muatan logis, terbukti secara empiris, dan terbebas dari unsur-unsur metafisik yang dipandang meaningless.

Pendirian tersebut bertentangan dengan pendapat Albert Einstein bahwa tugas tertinggi para fisikawan (ilmuwan) adalah meneliti hukum-hukum alam (yang berwatak metafisik), bukan sekedar mendeskripsikan fenomena-fenomena alamiah yang diderivasi dari hukum-hukum alam. Popper juga meyakini keniscayaan ide tentang hukum-hukum alam sangat penting secara metafisik (ontologis) dan intuitif bagi upaya memahami dunia. Popper menegaskan bahwa keniscayaan metafisik dalam kajian-kajian ilmiah karena ilmu pada prinsipnya bergerak menuju tujuan yang tidak terbatas, menemukan persoalan-persoalan yang selalu baru, lebih mendalam, dan lebih umum (Popper, 1972:36, 281, 438).

Uraian tersebut menyiratkan urgensi reintegrasi ilmu dan filsafat, melalui korelasi dan interkoneksi dimensi empiris dan dimensi metafisik, dalam rangka penguatan konstruksi ilmu yang berfondasikan filsafat. Urgensi pengembangan ilmu tidak hanya berdasarkan metodologi yang dibatasi oleh context of justification, tetapi juga atas dasar heuristik yang bergerak dalam context of discovery (Wibisono, 1997: 8). Perluasan konteks penyelidikan ilmiah meniscayakan dinamika ilmu mengatasi justifikasi metodologi positivistik, dan memahami kembali kaitan antara dimensi empiris dan dimensi metafisik ilmu. 
Popper (1972: 37) menegaskan bahwa keutamaan metafisika dalam kaitan integrasi tersebut bukan sekedar membuktikan kegagalan kaum positivis meruntuhkan metafisika, tetapi karena tuntutan signifikan dalam menjalin keterkaitan metafisika dengan ilmu-ilmu empiris itu sendiri. Karakteristik ilmu-ilmu empiris dapat dirumuskan secara tepat melalui penjalinan tersebut, dan ini merupakan suatu kajian utama tentang ilmu-ilmu empiris.

Integrasi tersebut juga dapat dijadikan dasar untuk memahami demarkasi ilmu (sistem pengetahuan empiris) dan filsafat (sistem pengetahuan metafisik), berdasarkan karakteristik "kebenaran". Ilmu hanya menghasilkan kebenaran "relatif-ideal" karena karakteristiknya yang empiris, dan filsafat dapat "menyingkap" kebenaran "absoluttransendental"- kebenaran yang mengatasi segala "klaim definitif" pemahaman manusia. Kebenaran ilmiah yang bersifat relatif-ideal dapat ditransendensikan secara terus-menerus dalam rangka menuju kebenaran absolut-transendental, karena ilmu tidak terlepas jalinannya dengan filsafat dalam "menyingkap" realitas metafisik yang tidak terbatas.

\section{REFLEKSI TERHADAP KONTEKS KEINDONESIAAN}

Strategi pengembangan IPTEK (Ilmu Pengetahuan dan Teknologi) di Indonesia dapat diaktualisasikan pada dua visi utama: 1) visi dan orientasi "filsafatinya" harus diletakkan pada nilai-nilai Pancasila sebagai cerminan budaya bangsa; dan 2) visi dan orientasi praksisnya harus diletakkan pada sifat-sifat teleologis, etis, dan integratif (Wibisono, 1997: 8). Sastrapratedja (2006: 10-11) juga menyatakan Pancasila sebagai dasar pengembangan etika ilmu pengetahuan dan teknologi di Indonesia, karena setiap sila dalam Pancasila dapat menjadi prinsip etis pengembangan tersebut.

Pengembangan ilmu dan teknologi yang berlandaskan Pancasila seharusnya menjadi prioritas utama dalam kehidupan bangsa Indonesia, karena ilmu dan teknologi merupakan salah satu faktor terpenting dalam proses perubahan tatanan kehidupan masyarakat, terutama dalam aspek sosial dan budaya. Perubahan ini sangat dipengaruhi oleh 
keberadaan ilmu-ilmu terkait, terutama ilmu-ilmu sosial dan ilmu-ilmu kemanusiaan (Humaniora).

Ilmu-ilmu sosial-budaya di Indonesia menghadapi sejumlah kritikan karena dipandang tidak mengalami perkembangan teoritis dan metodologis yang berarti, dan belum mampu mendorong lahirnya paradigma baru kecuali hanya bercorak positivistik (Ahimsa-Putra, 2008: 2). Fenomena serupa juga tercermin dari pemahaman sebagian ilmuwan sosial di Indonesia yang memandang dikotomi antara penelitian kualitatif dan penelitian kuantitatif sebagai dua paradigma yang mutually exclusive (Hidayat, 2008: 82).

Amin Abdullah (2010: 371) juga mengatakan bahwa dikotomi ilmu merupakan salah satu persoalan penting yang dihadapi negaranegara berkembang, termasuk Indonesia. Rumpun-rumpun ilmu: $\mathrm{Na}$ tural Sciences, Social Sciences, dan Humanities, tidak terjalin secara baik dalam bingkai interconnected entities. Para akademisi Natural Sciences, misalnya, tidak mengenal isu-isu penting yang berkembang dalam kajian-kajian Social Sciences, Humanities, dan terlebih lagi Religious Studies. Fenomena ini menciptakan fragmentasi intelektual dalam dunia akademis, terutama dalam pengembangan metodologi ilmiah, yang juga berdampak negatif dalam kehidupan masyarakat secara luas.

Dikotomi tersebut juga terkait dengan pernyataan Hathaway (2002: 212) bahwa pemahaman kaum objektivis (Natural Scientist) hanya dimungkinkan untuk menjelaskan dunia fisik, sebaliknya dunia human lazimnya dikaitkan dengan makna-makna subjektif yang harus diinterpretasi. Ilmu-ilmu kealaman dipandang menghasilkan pengetahuan objektif, sementara ilmu-ilmu kemanusiaan (Humanities) melahirkan bentuk-bentuk pemahaman lainnya.

Dampak dari dikotomi tersebut dapat meruntuhkan harmonisasi antarilmu. Ilmu yang satu tidak memberikan manfaat bagi ilmu yang lain, saling tidak membutuhkan, dan saling tidak mendukung satu sama lain, sehingga memunculkan berbagai permasalahan dalam berbagai aspek kehidupan masyarakat. Komunitas akademis justru terprimordialkan dalam paradigma atau rumpun ilmunya masing-masing, dan kelompok masyarakat lainnya senantiasa menanggung akibat dari polemik tersebut. 
Penjelasan tersebut mengambarkan dua persoalan pokok yang saling terkait, yaitu "krisis nilai Pancasila dalam paradigma ilmiah" dan "dikotomi antarrumpun ilmu". Kedua persoalan ini dapat dirumuskan ke dalam sebuah persoalan utama, yaitu disintegrasi ilmu di Indonesia. Persoalan disintegrasi ilmu dapat diantisipasi dengan pendekatan integratif, dalam rangka mengatasi dikotomi yang terjadi. Nasruddin Harahap (2009: 1) mengatakan bahwa integrasi ilmu mesti dipahami dengan terma interkoneksi, sebuah model penyatuan sehingga antara satu dengan lainnya punya keterkaitan kuat dan tampil dalam satu kesatuan yang utuh.

Hermeneutika Kuhn dan Popper juga dapat dikontribusikan bagi upaya integrasi ilmu-ilmu di Indonesia, sesuai dengan tuntutan nilainilai etika yang terkandung di dalam Pancasila. Kuhn dan Popper telah membuktikan bahwa "interpretasi" ternyata juga terlibat di dalam kajian-kajian ilmu-ilmu kealaman. Kuhn dan Popper juga memahami berbagai problematika ilmu-ilmu kealaman melalui interpretasi (hermeneutik), karena ilmu-ilmu tersebut pada prinsipnya juga mengandung muatan hermeneutik. Heelan (2003) mengatakan bahwa ilmuilmu kealaman bukanlah seutuhnya bertumpu pada metode eksplanasi (exclusively explanatory), dan ilmu-ilmu kemanusiaan bukan pula sepenuhnya bersandar pada metode interpretasi (exclusively interpretative). Habermas juga berpendapat bahwa terdapat kombinasi antara pemahaman hermeneutik (hermeneutical understanding) tentang keterlibatan manusia dalam kegiatan sosial tertentu dan penjelasan ilmiah (scientific explanation) tentang keberadaan setiap kegiatan tersebut (Gallagher, 2004: 163).

Strategi utama pengembangan ilmu (IPTEK) untuk masa depan di Indonesia meniscayakan upaya integrasi ilmu-ilmu kealaman dan ilmu-ilmu kemanusiaan. Ilmu-ilmu kealaman dan ilmu-ilmu kemanusiaan dapat dijalin secara interkonektif melalui kerangka metodologi perpaduan: "interpretasi" dan "eksplanasi" dengan berbagai derivasinya. Kedua bentuk metode ini dapat dipergunakan secara terpadu, baik dalam ilmu-ilmu kealaman maupun ilmu-ilmu kemanusiaan (dan ilmu-ilmu sosial yang terkait di dalamnya). 
Melalui integrasi tersebut nilai-nilai Pancasila akan dapat diaktualisasikan dalam kehidupan bangsa Indonesia. Integrasi dapat meningkatkan harkat dan martabat bangsa Indonesia, karena dapat memperkokoh sistem pendidikan sebagai pilar utama pembangunan nasional. Sifat integratif tersebut akan melahirkan penerapan ilmu untuk meningkatkan struktur, relasi, dan kultur masyarakat, karena para ilmuwan antarrumpun dan antarbidang ilmu akan saling bekerjasama dalam menyelesaikan berbagai permasalahan kehidupan, sehingga akan menciptakan harmonisasi dalam masyarakat. Pengembangan ilmu yang bersifat integratif merupakan penyangkalan segala bentukilmu yang bebas nilai (free value), sebagai perwujudan nilai-nilai Pancasila dalam kehidupan berbangsa, bernegara, dan bermasyarakat.

\section{SIMPULAN}

Hermeneutika Kuhn dan Popper merupakan kajian filosofis (metailmiah) tentang "meaning of truth", yang terkait dengan dasardasar dan prosedur pemahaman tentang kebenaran ilmiah dalam konteks kemajuan ilmiah. Hermeneutika bukan teori kebenaran atau pemahaman tentang klaim kebenaran (truth claim) berdasarkan ukuran atau pembuktian empiris tertentu.

Hermeneutika Kuhn merupakan antitesis terhadap pemahaman kaum skeptikus yang meragukan status kebenaran ilmiah yang dapat dicapai oleh pengetahuan ilmiah manusia. Kuhn mengajukan tesis tentang pluralitas kebenaran ilmiah, sebagai kebenaran fenomenologis, yang bersifat partikular dan relatif yang dapat dipahami berdasarkan paradigma masing-masing.

Hermeneutika Popper adalah antitesis terhadap pemahaman kelompok absolutis yang mengklaim kemungkinan pencapaian kebenaran absolut secara definitif. Popper menawarkan tesis tentang kebenaran tunggal yang bersifat absolut dan universal, sebagai kebenaran ontologis, yang mengatasi segala bentuk dogmatisme dan determinisme.

Persamaan esensial hermeneutika Kuhn dan Popper adalah mengakui "kebenaran relatif-ideal" sebagai satu-satunya bentuk kebenaran ilmiah yang mencitrakan "esensi" ilmu yang sesungguhnya. Perbe- 
daan fundamental hermeneutika Kuhn dan Popper menyangkut titiktolak pemahaman (modus interpretendi) masing-masing. Hermeneutika Kuhn bertitik-tolak dari dimensi "deskriptif" sehingga bercorak fenomenologis. Hermeneutika Popper bertitik-tolak dari dimensi "normatif" dan karenanya bercorak ontologis.

Hermeneutika Kuhn dan Popper dapat dikontribusikan sebagai landasan filosofis pengembangan ilmu untuk masa depan, terkait dengan pemahaman tentang wilayah penyelidikan ilmiah sebagai landasan ontologis; dialektika kemajuan ilmiah sebagai landasan epistemologis; dan menuju kebenaran absolut-transendental sebagai landasan aksiologis. Hermeneutika Kuhn dan Popper juga dapat dikontribusikan bagi upaya reintegrasi ilmu dan filsafat dalam rangka menjalin kembali korelasi dan interkoneksi dimensi empiris dan dimensi metafisik ilmu, dan dapat direfleksikan terhadap konteks ke-Indonesiaan dalam mewujudkan integrasi antarrumpun ilmu yang berlandaskan nilai-nilai etika Pancasila.

\section{DAFTAR PUSTAKA}

Abdullah, Amin, 2010, Islamic Studies di Perguruan Tinggi: Pendekatan Integratif-Interkonektif, Pustaka Pelajar, Yogyakarta.

Ahimsa-Putra, Heddy Shri, 2008, Paradigma dan Revolusi Ilmu dalam Antropologi Budaya, Pidato Pengukuhan Jabatan Guru Besar pada Fakultas Ilmu Budaya Universitas Gadjah Mada, 10 November, Yogyakarta.

Ambrosio, Francis J., 1987, “Gadamer, Plato, and the Discipline of Dialog", International Philosophical Quarterly, Vol. XXVII, No. 1, Issue No. 105, 17-32.

Blackburn, Simon, 1994, The Oxford Dictionary of Philosophy, Oxford University Press, Oxford.

Bleicher, Josef, 1980, Contemporary Hermeneutics: Hermeneutics as Method, Philosophy, and Critique, Routledge and Kegan Paul, London.

Capra, Fritjof, 2010, Sains Leonardo: Menguak Kecerdasan Terbesar Masa Renaisans, Terjemahan Heru Apriyono, Jalasutra, Yogyakarta. 
Gadamer, Hans-Georg, 1975, Truth and Method, Trans. by Sheed and Ward Ltd., The Seabury Press, New York.

Gadamer, Hans-Georg, 1976, Philosophical Hermeneutics, Trans. and ed. by David E.Linge, University of California Press, Los Angeles.

Gadamer, Hans-Georg, 1988, “On the Circle of Understanding”, dalam J.M. Conolly and T. Keutner (trans. and eds.), Hermeneutics Versus Science?, Indiana: University of Notre Dame Press, Notre Dame.

Gallagher, Shaun, 2004, "Hermeneutics and the Cognitive Sciences", Journal of Consciousness Studies, 11, No.10-11, 162-174.

Giddens, Anthony, 1976, New Rules of Sociological Method: A Positive Critique of Interpretative Sociologies, Hutchinson and Co. Ltd., London.

Hadi, Hardono, 1994, Epistemologi: Filsafat Pengetahuan, Kanisius, Yogyakarta.

Harahap, Nasruddin, 2009, Integrasi-Interkoneksi dalam Ilmu-ilmu Pengetahuan Alam dan Sosial: Perspektif paradigma tauhid, The 9th Annual Conference on Islamic Studies (ACIS), 2-5 November, Surakarta.

Hathaway, William L., 2002, “Integration as Interpretation: A Hermeneutical-Realist View", Journal of Psychology and Christianity, Vol. 21, No. 3, 205-218.

Hidayat, Dedy N., 2008, “Dikotomi Kualitatif-Kuantitatif dan Varian Paradigmatik dalam Penelitian Kualitatif", Jurnal Ilmiah Scriptura, Vol.2, No. 2, 81-94.

Hull, David L., 1996, “A Revolutionary Philosopher of Science”, Nature, Vol.382, 203-204.

Jacobs, S., and Mooney, B., 1997, "Sociology as a Source of Anomaly in Thomas Kuhn's System of Science", Philosophy of the Social Sciences, Vol. 27, No. 4, 466-485.

Jacob, T., 1993, Manusia, Ilmu dan Teknologi, PT. Tiara Wacana, Yogyakarta.

Klemke, E.D., 1981, “Popper's Criticism of Wittgenstein's Tractatus, dalam P.A. French, T.E. Uehling JR, and H.K. Wettstein, (eds.), 
Midwest Studies in Philosophy, Vol. VI, University of Minnesota Press, Minneapolis.

Kuhn, Thomas S., 1970a, The Structure of Scientific Revolutions, 2nd Edition (Enlarged), The University of Chicago Press, Chicago.

Lakatos, Imre, 1970, "Falsification and the Methodology of Scientific Research Programmes", dalam Imre Lakatos and Alan Musgrave (eds.), Criticism and the Growth of Knowledge, Cambridge University Press, Cambridge.

Laudan, Larry, 1981, "A Confutation of Convergent Realism", Philosophy of Science, Vol. 48, No. 1, 19-49.

Liang Gie, The, 2012, Pengantar Filsafat Ilmu, Cetakan ke-9, Liberty, Yogyakarta.

Muhadjir, Noeng, 2001, Filsafat Ilmu, Edisi II, Rake Sarasin, Yogyakarta.

Palmer, Richard E., 1969, Hermeneutics: Interpretation Theory in Schleiermacher, Dilthey, Heidegger, and Gadamer, Northwestern University Press, Evanston.

Popper, Karl R., 1970, "Normal Science and Its Dangers”, dalam Imre Lakatos and Alan Musgrave (eds.), Criticism and the Growth of Knowledge, Cambridge University Press, Cambridge.

Popper, Karl R., 1972, The Logic of Scientific Discovery, 2nd English Edition, Hutchinson and Co. Ltd., London.

Randall, J.H., and Buchler, J., 1942, Philosophy: An Introduction, Barnes and Noble, Inc., New York.

Sardar, Ziauddin, 2002, Thomas Kuhn dan Perang Ilmu, Terjemahan Sigit Djatmiko, Jendela, Yogyakarta.

Sastrapratedja, M., 2006, "Pancasila Sebagai Orientasi Pembangunan Bangsa dan Pengembangan Etika Ilmu Pengetahuan", Makalah Simposium dan Saresehan Pancasila sebagai Paradigma Ilmu Pengetahuan dan Pembangunan Bangsa, Kerjasama UGM-Kagama-LIPI.

Sumaryono, E., 1993, Hermeneutik: Sebuah Metode Filsafat, Kanisius, Yogyakarta.

Verhaak, C., dan Imam, P. Haryono, 1997, Filsafat Ilmu Pengetahuan, PT Gramedia Pustaka Utama, Jakarta. 
Wallis, Steven E., 2008, "Validation of Theory: Exploring and Reframing Popper's Worlds", Integral Review, Vol. 4, No. 2, 71-91.

Watkins, John, 1970, "Against 'Normal Science'”, dalam Imre Lakatos and Alan Musgrave (eds.), Criticism and the Growth of Knowledge, Cambridge University Press, Cambridge.

Wibisono, Koento, 1997, Filsafat Ilmu: Sebagai Dasar Pengembangan Ilmu Pengetahuan, LP3 UGM dan Intan Pariwara, Klaten.

\section{Sumber Internet:}

Charlton, BG., 2009, "The Vital Role of Transcendental Truth in Science", Medical Hypotheses, 72 (4), 373-6, http://www.ncbi. nlm.nih.gov/pubmed/ 19111996

Heelan, Patrick A., 2003, After Post-Modernism: The Scope of Hermeneutics in Natural Science, http://www.focusing.org/ apm_papers/heelan.html.

Lye, John, 1996, Some Principles of Phenomenological Hermeneutics, http://www.brocku.ca/english/ courses/4F70/ph.php.

Malhotra, Yogesh, 1994, On Science, Scientific Method And Evolution of ScientificThought: A Philosophy Of Science Perspective of QuasiExperimentation, http://www.brint.com/papers/science.htm.

Niiniluoto, Ilkka, 2011, "Scientific Progress", The Stanford Encyclopedia of Philosophy, Summer Edition, Edward N. Zalta (ed.), http:// plato.stanford.edu/archives/sum2011/entries/scientificprogress/. 